\author{
Kaspars Kikste \\ Postgraduate Student \\ ISMA University of Applied Sciences, Riga, Latvia \\ E-mail: kaspars.kikste@gmail.com \\ ORCID: https://orcid.org/0000-0002-9522-6349
}

\title{
Strategic imperatives of the formation of military security in the global world
}

\begin{abstract}
The military security is considered as an important part of national country's security. Military security is understood as the state of the country's security and its ability to neutralize external threats or internal tensions. Identification of threats and forecasting of conflicts is a key priority of military security and military policy. One of the important components of economic activity can be defined as the military sector as an object of economic management. Ensuring security is one of the key national security issues. In general, military security is understood as the state of a country in which there are opportunities to neutralize or stop destructive attempts to harm or threaten an individual, society, country, the world community, and destabilize peaceful coexistence. In general, the importance of the security system is undeniable for minimizing risks. The article considers the theoretical aspects of security system formation, levels of its implementation and key principles (the key principles of international security are renunciation of dictatorship, violence, equality of rights and interests, reduction of military forces or weapons). In general, the need for military-political cooperation and key aspects of security in a globalized world have been identified. It is determined that the peculiarity of the current stage of formation of the security system is its significant asymmetry on a global scale, the significant prevalence of leading countries by certain criteria over other countries or even associations. In general, in the structure of the military economy, this takes the place of preventing threats, neutralizing them and minimizing negative consequences.
\end{abstract}

Keywords

Military economy, military sector, national security, military security

JEL: F52, H56

\section{Introduction}

The formation of the economy is a complex process, as a result of which a system of relationships is formed between its industries and key actors. One of the important components of economic activity can be defined as the military sector as an object of economic management. Ensuring security is one of the key national security issues. In general, military security is understood as the state of a country in which there are opportunities to neutralize or stop destructive attempts to harm or threaten an individual, society, country, the world community, and destabilize peaceful coexistence. In general, this type of security is designed to ensure the gradual development of a country or society (economic, technological, etc.) (The military..., 2008).

The military sector is an important component of the economy of any country, since security is one of the key issues of national identity. In principle, defense refers to the so-called "public goods", which are understood as certain areas of social activity that require a special nature of functioning. In economic science, there are such types of goods ("goods") as private, public and mixed. Private goods are consumed by each individual personally. Moreover, acquiring a private good for himself, the individual thereby excludes others from consumption by this particular good. Virtually all goods are purchased in this way, based on a price distribution mechanism.

\section{Research review}

The study of the formation of defense economics is the basis of a significant number of works by the following scientists: Brömmelhörster D.J., Paes W. (Brömmelhörster, Paes, 2003), James Black, Richard Flint, Ruth Harris, Katerina Galai, Pauline Paille, Fiona Quimbre, Jess Plumridge (James Black and all, 2021), Arthur Cecil Pigou (Arthur Cecil Pigou, 1920), Charles J. Hitch, Roland McKean (Roland McKean, 1960), G. Kennedy (Kennedy, 1975), Todd Sandler, Keith Hartley (Todd Sandler, 1995) and others. Research is devoted to the problems of financing of defense economic: Rafael Calduch Cervera (Rafael Calduch Cervera, 2012), Buffotot P. (Buffotot, 2010), Crotty J. (Crotty, 2008), Kagan R. (Kagan, 2011), Rose A.K., Spiegel M.M. (Rose, 2009), Taylor J.B. (Taylor, 2008), Watts B. (Watts, 2008). The impact of military spending on the economy is explored in many more works: The Political Economy of War by Arthur Cecil Pigou (1920), Charles J. Hitch and Roland McKean The Economics of Defense in the Nuclear Age (1960), G. Kennedy published his book The Economics of Defence (1975), Todd Sandler and Keith Hartley The Handbook of Defense Economics (1995). At the same time, there is a lack of research of a systemic, complex nature, which would be devoted to the study of the essence and forms of manifestation of defense economics at different levels.

The purpose of the article is to determine the strategic imperatives of the formation of military security in the global world. 
To achieve this goal, the article uses the method of system-structural analysis to identify the main subjects and characterize their features in the context of the formation of military security in the global world.

\section{Results and discussions}

In the scientific literature, a very urgent problem is the study of the influence of military spending on macroeconomic indicators: GDP growth, investment dynamics, rate of return, employment, etc. Therefore, the more practical term "The Economics of Military Spending" is also used. Thus, Adem Yavuz Elveren in his book of the same name "The Economics of Military Spending a Marxist Perspective" (2019) conducts a comprehensive analysis of the impact of military spending on the economy. Exploring the military spending versus economic growth dilemma, this book uses econometric methods to comprehensively substantiate the impact of military spending on profit margins in more than 30 countries.

Defense also refers to the direct function of the state, and its main goal is to ensure the security of the country and its citizens. For the first time, such an understanding of the role of defense was laid down by Adam Smith, the founder of classical political economy and a free market economy. In his major work "An Inquiry into the Nature and Causes of the Wealth of Nations" (1776), Smith identified the protection of society as one of the primary functions of government. Acting on behalf of the entire community, the government collects taxes and uses them in such a way as to ensure the safety of the country and its people.

It is possible to define the military economy as a part of the economy that is directly related to the production of weapons. At the same time, this definition is very general and does not answer many questions. For example, for the production of any weapon (both small arms and nuclear), many components and spare parts are used, which are not necessarily produced by defense enterprises. Thus, the ultimate size of the defense economy can be very different.

At the same time, the question of the extent to which the country's security should be ensured remains controversial. Since this can be a fairly wide range of actions: from the presence of a minimal military contingent to an aggressive offensive policy. In each case, this is determined by the strategic goals and national interests of the country's leadership, the presence and severity of external threats, etc. In general, the obvious fact is that military spending is very significant in the modern world, although it can vary significantly between countries. Nevertheless, in each country, this sector - the military - is a special area that absorbs quite significant public funds.

In the scientific literature, there are different concepts to designate this sector of the economy: Military economy, War economy, Economics of war and peace, Defence economy.

In general, we can determine several key levels of military security: international, regional and national security. International military security consists in maintaining stable relations between countries or peoples, the absence of external military threats, the ability of countries to independently and independently choose their development paths (Military Security..., 2014).

In general, in the structure of the military economy, this takes the place of preventing threats, neutralizing them and minimizing negative consequences. The key principles of international security are renunciation of dictatorship, violence, equality of rights and interests, reduction of military forces or weapons. Such development is intended to form a global equilibrium system, however, given the financial capabilities of countries and their participation in the global redistribution of financial flows (including those involved in the military sector), such a model is quite complex and requires widespread attention and cooperation of key players in this market (National Security..., 2010).

Regional military security is implemented on the same principles, but concentrates exclusively on the countries of a certain region, is focused on achieving stability in the development of countries and resolving or preventing conflicts at the regional level.

An important aspect of the regional security system is the formation of military-political blocs or military-political cooperation. The prerequisites for the development of international military cooperation of countries may be the following circumstances: historical (historically established relations between countries), political (the presence of common political goals or threats), geographical (proximity to location), economic (the presence of stable long-term trade, financial and other aspects of cooperation) etc. Each of the above are important prerequisites for the development and deepening of cooperation in the military sphere. But one of the most important prerequisites is the presence of an external threat to the country's security. In the modern world, the number of such threats is growing rapidly. Along with such as religious extremism, terrorism, piracy, unfortunately, the threats associated with the predatory ambitions of individual countries, their aspirations to seize territories and the buildup of weapons of mass destruction do not disappear.

The economic potential of countries is very different, as a consequence of the different are their ability to withstand external threats. That is why the development of international cooperation with partner countries is the most important condition for strengthening its national security. The most developed form of international military cooperation is the creation of international military blocs.

The most successful military alliance is considered to be NATO (North Atlantic Treaty Organization) - a militarypolitical alliance of the states of North America and Europe, which have united their efforts to create collective defense, preserve peace and security. After the Russian aggression in 2014, NATO's activities take on particular importance for all countries in the region. NATO's priorities in this context are two areas - the Baltic region and the Black Sea region. The Baltic region is represented by NATO member states and two close partners - Sweden and Finland. The Black Sea region has three NATO members (Turkey, Romania and Bulgaria) and 3 partners (Ukraine, Georgia and Moldova).

The aggravation of the military-political situation in the world and in the region has as its consequence an increase in countries' expenditures for military purposes. An important task is to use the potential of international cooperation to reduce tensions, avoid military conflicts and achieve global stability.

The military security of the state in this context is understood as the state of the country's security and its ability to neutralize external threats or internal tensions. In 
this regard, it seems urgent to strengthen state cooperation in the military sector and the military economy, designed to create a system of collective defense and ensure the interests of a particular state at the regional and global level. In general, timely identification of threats and forecasting of conflicts is a key priority of military security and military policy.

Another important issue is the definition of the product - the result of the war economy. What is the result of manufacturing in the military sector? It seems to us that two levels of the results of the military economy can be distinguished:

The first is directly what is produced by military enterprises.

The second is what matters to the whole society. In this case, we are talking about the value that defense brings as a public good. These values include: security of the population and the country; protection against terrorism; impact on economic growth and technological progress.

Rand corporation researchers prepared an in-depth report on the assessment of the cost of the defense sector to the country's economy (James Black and others, 2021). They identify six important components of the value of defense for a country's economy:

The first component of value focuses on protecting the UK's people against today's myriad security threats, risks and hazards.

The second component of value focuses on the role of defense as the insurance policy of both government and society against an uncertain future.

The third component of value focuses on the benefits that defence brings to the UK's influence and standing with allies, partners and potential adversaries.

The fourth component of value focuses on the contribution of UK defence to wider international security, tackling the causes of instability and conflict.

The fifth component of value focuses on the direct and indirect benefits that defence provides to the UK economy, enabling trade, industry and innovation.

The final component of value focuses on the role of defence as a vital part of the UK's national identity, social cohesion and local communities.

In a broad sense, defense policy is not limited to the use of military force to deter, stop or repel any aggression against a national territory, but also implies the obligation of the armed forces outside its borders to protect universal values such as human values, human rights or respect for international law, or national interests (René Van Beveren, 1993).

In this context, it is important to identify the key players in this market, the countries with the largest financing of the military sector and an established market, for example, the first place in the world in 2021 for the level of financing of the military sector is occupied by the United States of America with a budget of $\$ 740.5$ billion, for second place is China with the amount of 178.2 billion dollars. and closes the TOP-3 India with a budget of 73.65 billion dollars. In general, the US budget is more than the budget of the rest of the TOP-10 countries in terms of the level of funding for the military sector (Defense..., 2021).

To assess the military power of countries in the global economy, the Global Firepower rating is used, within which averaged indicators are taken for individual criteria in order to determine not only the country's power in the current period, but also its potential. The index takes into account military forces, funding, logistical capabilities, and geographic factors. In general, this approach allows us to include in the rating countries with great potential, for example, in the field of scientific research in the military complex (Table 1).

TABLE 1 TOP-10 countries in the Military Strength Ranking (Defense..., 2021)

\begin{tabular}{|c|c|c|}
\hline Rank & \multicolumn{1}{|c}{ Country } & Point \\
\hline 1 & USA & 0,0718 \\
\hline 2 & Russian federation & 0,0791 \\
\hline 3 & China & 0,0854 \\
\hline 4 & India & 0,1207 \\
\hline 5 & Japan & 0,1599 \\
\hline 6 & Republic of Korea & 0,1612 \\
\hline 7 & France & 0,1681 \\
\hline 8 & United Kingdom & 0,1997 \\
\hline 9 & Brazil & 0,2026 \\
\hline 10 & Pakistan & 0,2073 \\
\hline
\end{tabular}

However, within the framework of the rating, we can observe quite significant asymmetries, both in the overall rating score and in the key components. In the rating itself, a point tending to 0 is considered ideal, we can note that the gap between the countries of the first three and subsequent ones is quite large. However, for example, the United States of America, which occupies the first place in the overall ranking, is only 139th in terms of the number of military and the number of paramilitaries, the first place behind this indicator is for Bangladesh. The United States also occupies 139th place in terms of the number of frigates, where China holds the first place with an indicator of 44 , at the same time, there is no such military unit in the United States at all. However, the United States is realizing its leadership in the "navy" category through the presence of aircraft carriers, helicopter carriers, destroyers and submarines.

The rating also includes all infrastructure that may be involved in the military sector, for example, airports, merchant navy, ports or trading terminals, road surface, railway connections, labor force, etc.

Defense exists in order to prevent war, to prevent such losses. Nevertheless, the size of the military sector in each country is determined by a whole range of factors: geopolitical, regional, political, economic, historical, technological, etc.

Geopolitical factors: general geopolitical situation in the world; common threats: terrorism, instability, confrontation between the main centers of power in the world.

Regional: location of the country; proximity to hotbeds of tension; access to the sea; the presence of neighboring countries with different peace-loving aspirations.

Political: leading ideology; the nature of political power in the country; goals and principles of the ruling party; weak governance; presence of corruption; the strength of political clans associated with the defense sector.

Economic: the level of development of the country; economic opportunities for financing military spending; economic and social inequality; poverty and unemployment rates. 
Historical: history of wars on the territory of the country; predisposition to aggressive or peaceful military policy; cultural and mental closeness with neighboring countries.

Technological: the level of scientific and technological development of the armed forces of the country and in the world; opportunities for R\&D in the military sphere; the need to maintain their Armed Forces at the level of global standards; In general, analyzing military security, we can note that it is only a part of national security and takes on the functions of stimulating the activity of all forces and actors to ensure the protection of the interests of the country and the community, developing measures to forestall potential and real threats, forming military forces and control power structures, ensuring the stability of the development of society and maintaining law and order, state cooperation in the military sphere (for the formation of a collective defense system, including), detecting threats and assessing the potential for their development and implementation in a particular country (Military Aspects..., 2021).

\section{Conclusion}

It can be noted that in modern society, the military economy and military security are an important part of the functioning of the country and the formation of global stability. The military-technical cooperation between countries is a necessary aspect of national military security. The most developed form of military cooperation is the country's participation in military alliances and blocs. This allows each participating country to multiply its national security.

The formation of a stable military economy is a necessary prerequisite for ensuring the country's military security, ensuring it at all levels - from national to global. Determining the key principles for the functioning of the military economy can provide an understanding of the framework of its functioning and the key directions of development. However, it should be noted that the issue of observance of national interests in the system of building a global system of military-political security requires careful study.

\section{References}

[1] Brömmelhörster D. J., \& Paes, W. (2003) The Military as an Economic Actor: Soldiers in Business, Palgrave Macmillan.

[2] Buffotot, P. Endettement et défense. Les conséquences de la crise de l'endettement sur la défense. Défense et Stratégie; no. 29 (Eté 2010), pp. 16-28. E-source: http://mjp.univ-perp.fr/defense/ds29.pdf

[3] Crotty, J. (2008). Structural Causes of the Global Financial Crisis: A Critical Assessment of the "New Financial Architecture". Economics Department Working Paper Series, no. 16, 61 p. E-source: http://scholarworks.umass.edu/ cgi/viewcontent. cgi?article=1017\&context= econ_workingpaper

[4] Defense Spending by Country (2021). E-source: https://www.globalfirepower.com/defense-spending-budget.php

[5] Defense Spending by Country (2021). E-source: https://www.globalfirepower.com/defense-spending-budget.php

[6] G. Kennedy (1975). The Economics of Defence.

[7] James Black, Richard Flint, Ruth Harris, Katerina Galai, Pauline Paille, Fiona Quimbre, Jess Plumridge (2021). Understanding the Value of Defence: Towards a Defence Value Proposition for the UK. Rand Europe.

[8] Kagan, R. (2003). Poder y debilidad. Madrid. Taurus.

[9] National Institute For Defense Studies (2011). The Global Financial Crisis and International Security: Impacts on Defense Budgets of Major Countries. East Asian Strategic Review, pp. 10-55. E-source: http://www.nids.go.jp/english/ publication/east-asian/pdf/2011/east-asian_e2011_01.pdf

[10] Military Aspects of Security (2021). E-source: https://www.csce.gov/issue/military-aspects-security

[11] René Van Beveren (January 1993). Military Cooperation: What Structure For The Future?

[12] Military Security within the Framework of Security Studies: Research Results. Connections, vol. 13, no. 3 (Summer 2014), pp. 59-82. E-source: https://www.jstor.org/stable/26326368?seq=1\#metadata_info_tab_contents

[13] Paleri, Prabhakaran (2008). National Security: Imperatives and Challenges. New Delhi: Tata McGraw-Hill, p. 521.

[14] Rafael Calduch Cervera (2012). Impact of the economic crisis on defence policies. E-source: https://dialnet.unirioja.es/ descarga/articulo/4098274/2.pdf

[15] Roland McKean (1960). The Economics of Defense in the Nuclear Age.

[16] Rose, A. K., \& Spiegel, M. M. (July, 2009). Cross-Country Causes and Consequences of the 2008 Crisis: Early Warning. Federal Reserve Bank of San Francisco. Working Papers Series, no. 17, 53 p. E-source: http://www.frbsf.org/ publications/economics/papers/2009/wp09-17bk.pdf

[17] SIPRI (2011). Background Paper on SIPRI Military Expenditure Data 2010.

[18] Taylor, J. B. The Financial Crisis and the Policy Responses: An Empirical Analysis of What Went Wrong.

[19] The military and human security. E-source: https://www.clingendael.org/sites/default/files/pdfs/20080100_cscp_ art_homan_security.pdf

[20] The Political Economy of War by Arthur Cecil Pigou (1920), Charles J. Hitch.

[21] Todd Sandler and Keith Hartley The Handbook of Defense Economics (1995).

[22] Watts, B. (2008). The US Defense Industrial Base: Past, Present and Future. Washington. Center for Strategic and Budgetary Assessments. E-source: http://www.csbaonline.org/4Publications/PubLibrary/R.20081015._The_US_ Defense_In/R.20081015._The_US_Defense_In.pdf 